\title{
Presynaptic Localization of Sodium/Calcium Exchangers in Neuromuscular Preparations
}

\author{
Paul W. Luther, ${ }^{1}$ Rick K. Yip, ${ }^{1}$ Robert J. Bloch, ${ }^{1}$ Anthony Ambesi, ${ }^{2, a}$ George E. Lindenmayer, ${ }^{2}$ and Mordecai P. \\ Blaustein' \\ 'Department of Physiology, University of Maryland, School of Medicine, Baltimore, Maryland 21201 and ${ }^{2}$ Department of \\ Pharmacology, Medical University of South Carolina, Charleston, South Carolina 29425
}

\begin{abstract}
Calcium ions play a critical role in neurotransmitter release. The cytosolic $\mathrm{Ca}^{2+}$ concentration $\left(\left[\mathrm{Ca}^{2+}\right]_{\text {cyn }}\right)$ at nerve terminals must therefore be carefully controlled. Several different mechanisms, including a plasmalemmal $\mathrm{Na} / \mathrm{Ca}$ exchanger, are involved in regulating $\left[\mathrm{Ca}^{2+}\right]_{\mathrm{cy} \text {. }}$. We employed immunofluorescence microscopy with polyclonal antiserum raised against dog cardiac sarcolemmal $\mathrm{Na} / \mathrm{Ca}$ exchanger to determine the distribution of the exchanger in vertebrate neuromuscular preparations. Our data indicate that the $\mathrm{Na} / \mathrm{Ca}$ exchanger is concentrated at the neuromuscular junctions of the rat diaphragm. The exchanger is also present in the nonjunctional sarcolemma, but at a much lower concentration than in the junctional regions. Denervation markedly lowers the concentration of the exchanger in the junctional regions; this implies that the $\mathrm{Na} / \mathrm{Ca}$ exchanger is concentrated in the presynaptic nerve terminals. In Xenopus laevis nerve and muscle cell cocultures, high concentrations of the exchanger are observed along the neurites as well as at the nerve terminals. The high concentrations of $\mathrm{Na} / \mathrm{Ca}$ exchanger at presynaptic nerve terminals in vertebrate neuromuscular preparations suggest that the exchanger may participate in the Ca-dependent regulation of neurotransmitter release. The $\mathrm{Na} / \mathrm{Ca}$ exchanger is also abundant in developing neurites and growth cones, where it may also be important for $\mathrm{Ca}^{2+}$ homeostasis.
\end{abstract}

Numerous cellular functions in higher organisms are governed by changes in the cytosolic free calcium concentration, $\left[\mathrm{Ca}^{2+}\right]_{\mathrm{cyt}}$. In neurons, for example, $\left[\mathrm{Ca}^{2+}\right]_{\mathrm{cyt}}$ regulates such diverse processes as transmitter release, potassium conductance, various enzyme activities, growth cone motility, and axoplasmic transport (reviewed in Blaustein, 1988a,b). Consequently, $\left[\mathrm{Ca}^{2+}\right]_{c y t}$ must be spatially and temporally controlled. One of the mechanisms involved in controlling $\left[\mathrm{Ca}^{2+}\right]_{\mathrm{cy}}$ in neurons is the plasmalemmal $\mathrm{Na} / \mathrm{Ca}$ exchanger (Sanchcz-Armass and Blaustcin, 1987; Blaustein, 1988a; DiPolo and Beaugé, 1990). This ex-

\footnotetext{
Received Apr. 24, 1992; revised July 8, 1992; accepted July 9, 1992.

We thank G. Porter for the image of the cryosection labeled with $\beta$-spectrin, A. O'Neill for technical assistance, and Dr. B. E. Alger for comments on the manuscript. This work was supported by NIH Grants HL-42040, NS-16106, NS17282, and NS-27171 and a grant from the Muscular Dystrophy Association.

Correspondence should be addressed to Mordccai P. Blaustein, M.D., Department of Physiology, University of Maryland School of Medicine, 655 West Baltimore Street, Baltimore, MD 21201.

apresent address: Department of Genetics, Yale University School of Medicine, New Haven, CT 06510.

Copyright (C) 1992 Society for Neuroscience $0270-6474 / 92 / 124898-07 \$ 05.00 / 0$
}

changer can transport $\mathrm{Ca}^{2+}$ either into or out of cells, depending upon the prevailing $\mathrm{Na}^{+}$electrochemical gradient. The distribution of the $\mathrm{Na} / \mathrm{Ca}$ exchanger in neurons, and its precise role in neuronal function are uncertain. However, studies of the influence of the $\mathrm{Na}^{+}$gradient on $\mathrm{Ca}^{2+}$ fluxes in nerve terminals (Blaustein et al., 1991; Fontana and Blaustein, 1991) and on neurotransmitter release (Meiri et al., 1981; Atwood et al., 1983; Misler and Hurlburt, 1983; Zucker et al., 1991) raise the possibility that the $\mathrm{Na} / \mathrm{Ca}$ exchanger may be concentrated in nerve terminals.

Polyclonal antibodies raised against the partially purified $\mathrm{Na} /$ $\mathrm{Ca}$ exchanger from dog heart react with proteins of molecular masses of about $140-160,120$, and $70 \mathrm{kDa}$ from dog cardiac sarcolemma (Philipson et al., 1988; Ambesi et al., 1991) and with similar molecular mass proteins from rat brain (Yip et al., 1992; see also Results). This suggests that brain and heart contain $\mathrm{Na} / \mathrm{Ca}$ exchangers that are structurally similar; they also have similar kinetic properties (Blaustein et al., 1991; Fontana and Blaustcin, 1991). The $70 \mathrm{kDa}$ polypeptide appears to be a proteolytic fragment of the exchanger (Nicoll et al., 1990). It is unclear whether the $120 \mathrm{kDa}$ or the $140-160 \mathrm{kDa}$ peptide is the native protein. Nicoll et al. (1990) have suggested that the 120 $\mathrm{kDa}$ protein corresponds to the mature, glycosylated $\mathrm{Na} / \mathrm{Ca}$ exchanger. The higher-molecular-weight polypeptide, which is usually most prominent under nonreducing conditions (Nicoll et al., 1990; Durkin et al., 1991a,b; Yip et al., 1992), especially after boiling (Durkin et al., 1991a), may reflect a change in the conformational state of the exchanger during preparation for SDS-PAGE (Durkin et al., 1991a,b).

In the present study, we employed immunofluorescence techniques with polyclonal antiserum raised against the dog heart $\mathrm{Na} / \mathrm{Ca}$ exchanger to determine the distribution of the exchanger in a readily accessible preparation, the vertebrate neuromuscular junction (NMJ). One aim of this study was to test the prediction that the $\mathrm{Na} / \mathrm{Ca}$ exchanger may be concentrated at nerve terminals.

\section{Materials and Methods}

Immunoblotting. Particulate fractions (containing plasma membranes) were prepared from Polytron (Brinkmann, Westbury, NY) homogenates of tissues (adult rat brain, spinal cord, sciatic nerve, and skeletal muscle; Xenopus laevis brain) by centrifuging at $16,000 \times g$ for $10 \mathrm{~min}$ at $4^{\circ} \mathrm{C}$. Proteins from the pellets were solubilized by boiling $(5 \mathrm{~min})$ in SDS buffer containing $15 \mathrm{~mm}$ dithiothreitol, and were separated by SDSPAGE (Yip et al., 1992). The proteins were transferred to nitrocellulose (Yip et al., 1992), which was subsequently incubated with immune serum (Ambesi et al., 1991) or preimmune serum (1:500 dilutions) 
overnight at $4^{\circ} \mathrm{C}$, and then with $5 \times 10^{5} \mathrm{cpm} / \mathrm{ml}{ }^{125} \mathrm{I}$-protein $\mathrm{A}$ (Amersham, Arlington Heights, IL) for $2 \mathrm{hr}$ at room temperature. The immunoblots were analyzed by autoradiography on Kodak (Rochester, NY) X-Omat AR film.

Polyclonal antiserum directed against partially purified dog heart sarcolemmal $\mathrm{Na} / \mathrm{Ca}$ exchanger was employed for these studies. This antiserum was raised in rabbits, as described previously (Ambesi et al., 1991).

Immunocytochemistry. Diaphragms from adult rats were frozen in a slush of liquid $\mathrm{N}_{2}$. Cryosections, $4 \mu \mathrm{m}$ thick, were cut through the innervated portions of the muscle. The sections were incubated in antiserum or preimmune serum, both diluted 1:1000, followed by $10 \mu \mathrm{g} /$ $\mathrm{ml}$ affinity-purified fluoresceinated goat anti-rabbit IgG secondary antibody (Jackson Immunoresearch, West Grove, PA). Tetramethylrhodamine- $\alpha$-bungarotoxin was included with the secondary antibody to label acetylcholine ( $\mathrm{ACh}$ ) receptors. Fluorescent images were observed with a Zeiss IM-35 microscope and photographed on Kodak TMAX 3200 film processed to an ASA of 1600 .

Nerve and muscle cell cocultures were prepared from Xenopus embryos (Anderson et al., 1977). Cultures ( $2-4$ d) were labeled with tetramethylrhodamine- $\alpha$-bungarotoxin and fixed with formaldehyde-cyclohexylamine fixative $[0.5 \%$ paraformaldehyde, $75 \mathrm{~mm}$ cyclohexylamine, $10 \mathrm{mM} \mathrm{MgCl}_{2}$, and $10 \mathrm{~mm}$ PIPES (1,4-piperazine diethane sulfonic acid) at $\mathrm{pH} 6.5$; Luther and Bloch, 1989]. The cultures were permeabilized for $5 \mathrm{~min}$ in $0.5 \%$ Brij 58 (Sigma, St. Louis, MO) prepared in the same fixative, and washed twice with a solution containing $10 \mathrm{mM}$ $\mathrm{MgCl}_{2}$ and $75 \mathrm{~mm}$ Tris, $\mathrm{pH}$ 7.4. Nonspecific binding was blocked by incubating the cultures for $30-60 \mathrm{~min}$ in a solution containing $0.1 \%$ bovine serum albumin, $0.5 \mathrm{mM} \mathrm{NaCl}, 10 \mathrm{mM} \mathrm{MgCl}_{2}, 10 \mathrm{mM} \mathrm{NaN}_{3}$, and $75 \mathrm{~mm}$ Tris, $\mathrm{pH} 7.4$. The cultures were then incubated overnight $\left(4^{\circ} \mathrm{C}\right)$ with the antiserum (diluted $1: 1000$ ) or with affinity-purified anti- $\mathrm{Na} /$ $\mathrm{Ca}$ exchanger antibodies $(0.5 \mu \mathrm{g} / \mathrm{ml})$ or similarly treated preimmune serum. After three washes in the blocking buffer, the cultures were incubated overnight in affinity-purified fluoresceinated goat anti-rabbit $\mathrm{IgG}(5 \mu \mathrm{g} / \mathrm{ml})$. Fluorescent images were collected with a slow-scan chargecoupled device camera (Star 1, Photometrics, Tucson, AZ) attached to a Zeiss IM-35 microscope.

Preparation of affinity-purified anti- $\mathrm{Na} / \mathrm{Ca}$ exchanger antiserum. $\mathrm{Car}-$ diac sarcolemmal proteins, separated by SDS-PAGE, were transferred onto Immobilon-P (Millipore, Bedford, MA). The 140, 120, and 70 $\mathrm{kDa}$ bands were identified with the polyclonal anti- $\mathrm{Na} / \mathrm{Ca}$ exchanger antiserum (Ambesi et al., 1991). Strips containing these bands were removed and exposed to a 500 -fold dilution of the antiserum. The antibodies were eluted with a glycine- $\mathrm{HCl}$ buffer $(\mathrm{pH} 2.8)$. "Affinitypurified" fractions from preimmune serum were obtained in identical fashion.

\section{Results}

\section{Immunoblot identification of the $\mathrm{Na} / \mathrm{Ca}$ exchanger}

A polyclonal rabbit antiserum raised against purified canine cardiac $\mathrm{Na} / \mathrm{Ca}$ exchanger (Ambesi et al., 1991) was used to identify the $\mathrm{Na} / \mathrm{Ca}$ exchanger in neuronal preparations. The immunoreactivity of particulate fractions (containing plasmalemma) prepared from homogenates of rat cerebral cortex, spinal cord, and sciatic nerve were compared (Fig. 1, lanes 2-4). Little specific labeling was detected in the sciatic nerve fraction, but fractions from the brain and spinal cord exhibited crossreacting bands that were similar to those seen in canine cardiac preparations (Nicoll et al., 1990; Ambesi et al., 1991; Yip et al., 1992). Similar high-molecular-weight bands (about 135,000 165,000 ) from the particulate fraction of a homogenate of Xenopus brain also specifically cross-reacted with the antiserum (Fig. 1, lane 7). This evidence that the exchanger in the nervous system of lower vertebrates is immunologically and structurally similar to the exchanger from canine cardiac sarcolemma implies that the exchanger is highly conserved. Cross-reactivity of protein from the particulate fraction of rat skeletal muscle homogenates was also observed at 170 and $120 \mathrm{kDa}$, but the strongest specific cross-reactivity was seen at about $220 \mathrm{kDa}$ (Fig. 1, lane 1). The significance of this apparently high-molec-
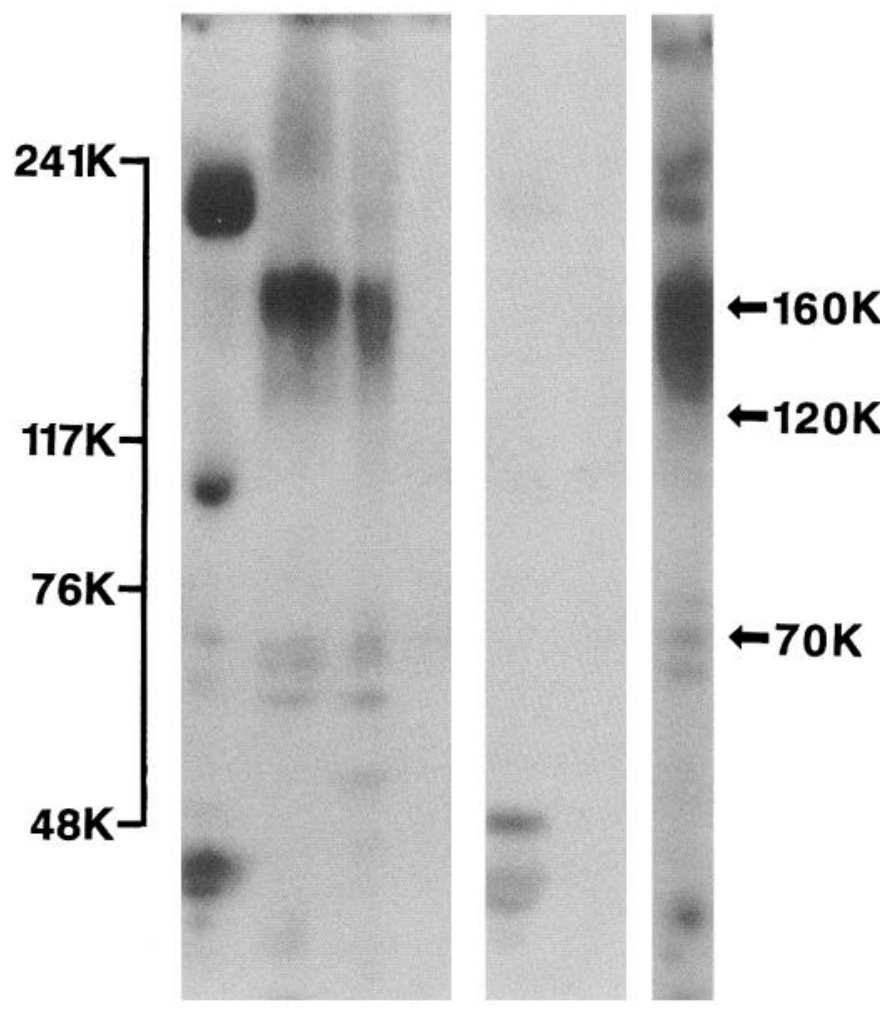

\section{$\begin{array}{lllllll}1 & 2 & 3 & 4 & 5 & 6 & 7\end{array}$}

Figure 1. Immunoblot of proteins from rat and Xenopus tissues incubated with preimmune serum or anti-Na/Ca exchanger antiserum. Particulate fractions containing plasma membrane (lanes 1-6, $40 \mu \mathrm{g}$ protein/lane; lane 7, $30 \mu \mathrm{g}$ ) from rat brain (lanes 2 and 6), spinal cord (lane 3), sciatic nerve (lane 4), and skeletal muscle (lanes 1 and 5), and Xenopus brain (lane 7), were probed with preimmune serum (lanes 5 and 6 ) or $\mathrm{Na} / \mathrm{Ca}$ exchanger antiserum (lanes 1-4 and 7).

ular-weight band is unclear; it may represent a form of the exchanger unique to skeletal muscle.

\section{Immunolocalization of $\mathrm{Na} / \mathrm{Ca}$ exchanger in rat diaphragm}

This antiserum was used as a probe to determine the distribution of $\mathrm{Na} / \mathrm{Ca}$ exchangers at $\mathrm{NMJs}$ by indirect immunofluorescence. In cryosections of rat diaphragm muscle, labeling by anti-exchanger antibodies is concentrated at NMJs (Fig. $2 A$ ) identified by labeling the sections with fluorescent $\alpha$-bungarotoxin (Fig. $2 B, D, F)$, a specific probe for ACh receptors. Comparison of the labeled sections (Fig. $2 A$ ) with controls incubated in preimmune serum (Fig. $2 C$ ) indicates that extrajunctional sarcolemma was also specifically labeled, but at a much lower level relative to the intense labeling of the synaptic regions.

We did not observe labeling for the $\mathrm{Na} / \mathrm{Ca}$ exchanger in extrasynaptic nerve cut in cross section (Fig. $2 G$ ) or longitudinally (not shown), although the antibodies had access to the axoplasm (Fig. $2 H$ ); this raises the possibility that the exchanger is concentrated at the presynaptic terminals. Further evidence for this possibility was obtained by labeling rat diaphragm that had been denervated for 5 weeks before freezing and sectioning. Comparison of Figure 2, $A$ and $E$, indicates that synaptic labeling for $\mathrm{Na} / \mathrm{Ca}$ exchanger was reduced by denervation. Some labeling is expected at the denervated synapse because, even though the sarcolemma is only lightly labeled, postjunctional folds increase the membrane surface area at this site. 

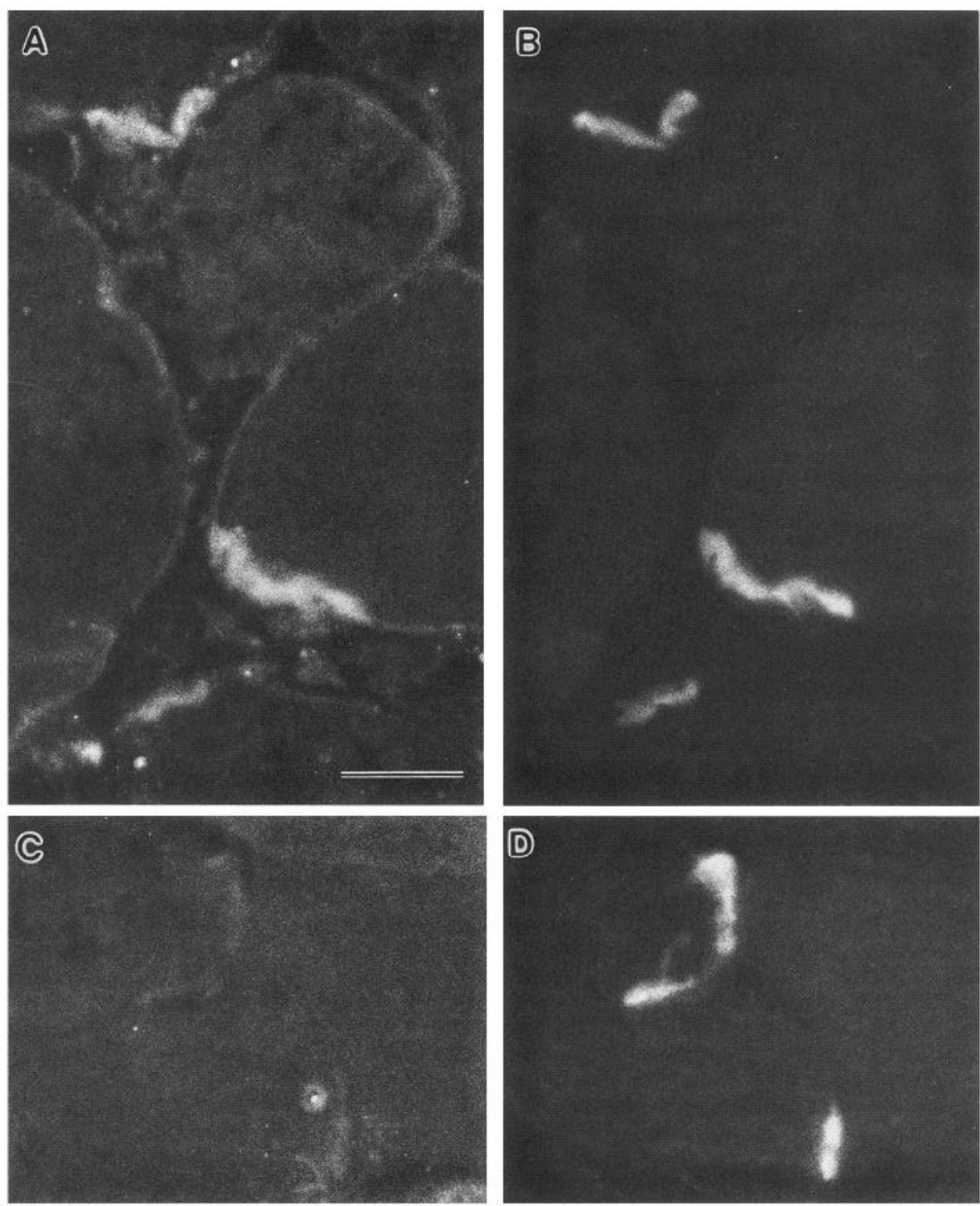

Figure 2. Immunofluorescent labeling of $\mathrm{Na} / \mathrm{Ca}$ exchanger in cryosectioned rat diaphragm. $A$, Cross-sectioned myofibers were incubated with anti- $\mathrm{Na} / \mathrm{Ca}$ exchanger antiserum followed by a fluorescein-conjugated secondary antibody. $B$, The same section labeled with rhodamine- $\alpha$-bungarotoxin to localize NMJs. Anti-exchanger labeling is concentrated at the NMJs. $C$ and $D$, Similar to $A$ and $B$, respectively, but incubated with preimmune rabbit serum; no labeling is seen in $C . E$ and $F$, Similar to $A$ and $B$, respectively, but from a diaphragm that had been denervated for 5 weeks. Labeling in junctional regions is greatly reduced. $G$, Cross section of rat phrenic nerve incubated with anti- $\mathrm{Na} / \mathrm{Ca}$ exchanger antiserum, followed by fluorescein-conjugated secondary antibody. No labeling is seen in the axolemma. $H$, Cross section of nerve incubated with anti-spectrin antibodies, followed by fluorescein-conjugated secondary antibody. The axonal membranes are labeled (arrows), demonstrating that antibodies have access to the cytoplasmic surface of the axolemma in these preparations. Scale bars: $A, 20 \mu \mathrm{m}$ for $A-F ; G, 20 \mu \mathrm{m}$ for $G$ and $H$.
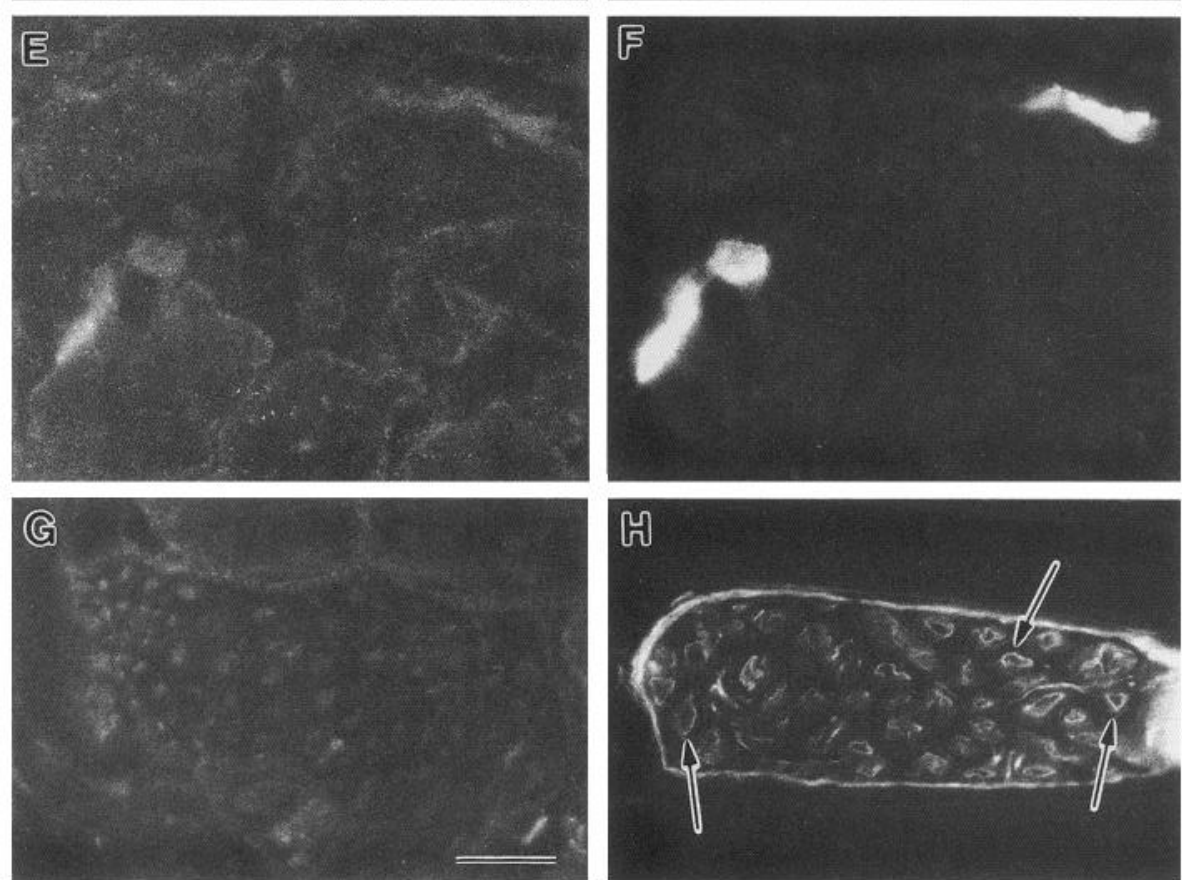

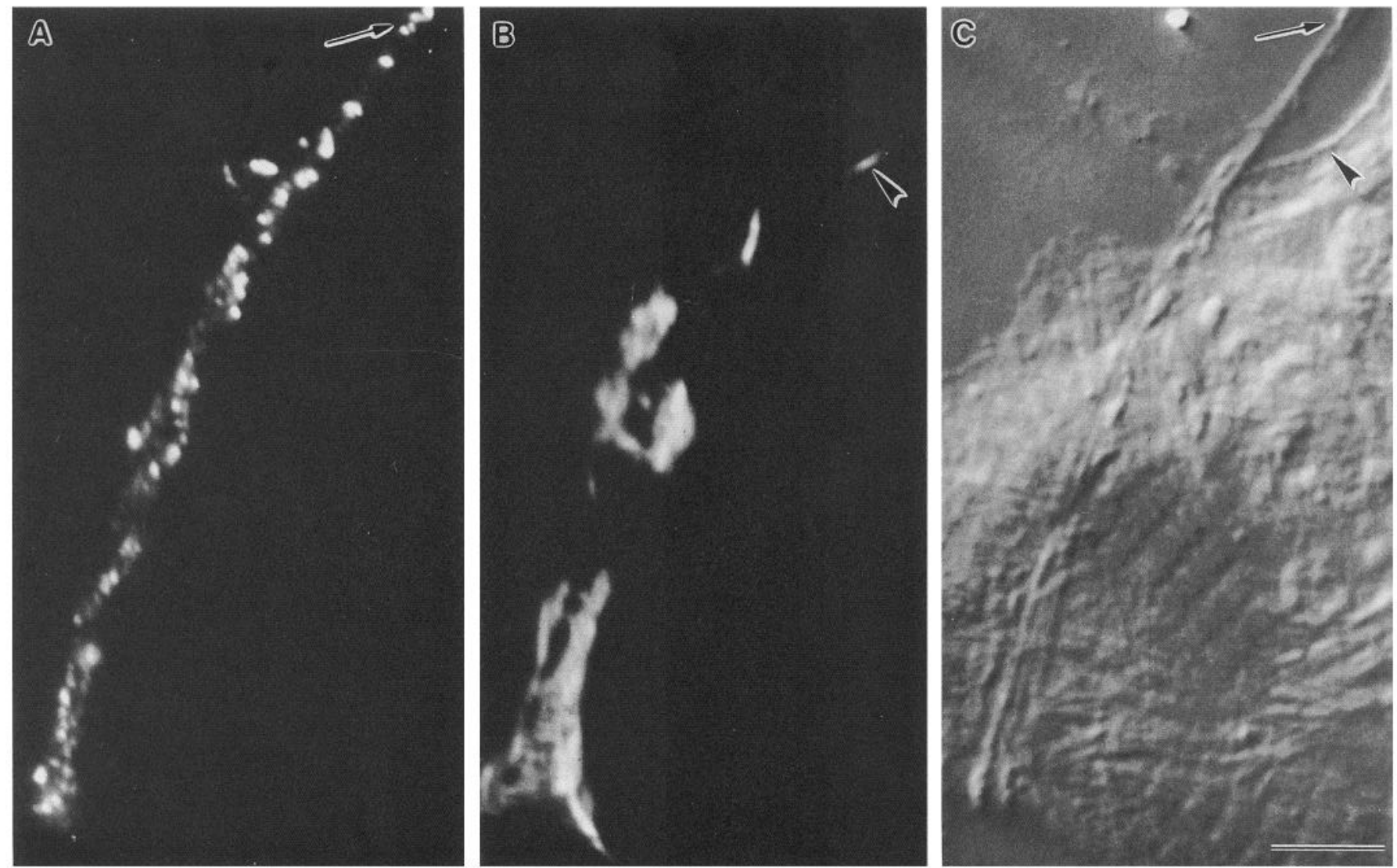

Figure 3. Immunofluorescent labeling of $\mathrm{Na} / \mathrm{Ca}$ exchanger at a synapse between cultured Xenopus nerve and muscle cells. A, Cells labeled with affinity-purified anti-Na/Ca exchanger antibodies followed by a fluorescein-conjugated secondary antibody. $B$, Postjunctional ACh receptors in the same cells labeled with rhodamine-conjugated $\alpha$-bungarotoxin. $C$, Differential interference contrast micrograph of the same cells. Note that the entire length of the axon is labeled by anti- $\mathrm{Na} / \mathrm{Ca}$ exchanger antibodies, even in the region where the nerve and muscle cells are not in contact (arrows in $A$ and $C$ ), whereas $\alpha$-bungarotoxin labels perijunctional (arrowheads in $B$ and $C$ ) as well as junctional ACh receptor aggregates. Scale bar, $5 \mu \mathrm{m}$.

\section{Immunolocalization of $\mathrm{Na} / \mathrm{Ca}$ exchangers in Xenopus nerve and muscle cell cocultures}

The preceding observations establish that the $\mathrm{Na} / \mathrm{Ca}$ exchanger is concentrated at NMJs. They are consistent with an enrichment of the exchanger in the presynaptic terminal, but they are not definitive because of the persistent postjunctional labeling after denervation. Additional studies on the distribution of the $\mathrm{Na} / \mathrm{Ca}$ exchanger were therefore performed on cocultures of Xenopus nerve and muscle cells. These preparations have several important advantages. NMJs form between individual cells in this system; thus, the distribution of the exchanger can be evaluated at intact synapses without sectioning. Furthermore, these synapses do not have Schwann cells or postjunctional folds (Weldon and Cohen, 1979), so interpretation of synaptic labeling is unambiguous. Figure $3 A$ shows the results obtained when cultured NMJs were labeled with affinity-purified anti-Na/Ca exchanger antibody. Intense labeling was limited to the neuron, which is visible in the interference-contrast micrograph of the same synapse (Fig. $3 C$ ). Labeling did not extend beyond the nerve contact as postjunctional $\mathrm{ACh}$ receptor aggregates do (Fig. $3 B$, arrowhead). Figure 4 displays the superimposed, pseudocolor distribution of the $\mathrm{Na} / \mathrm{Ca}$ exchanger (green) and $\mathrm{ACh}$ receptors (red) from Figure 3, $A$ and $B$, respectively; the myocyte and neuron (from Fig. 3C) are shown in blue. The fact that intense anti-exchanger labeling was confined to the neuron was most evident at synapses where part of the nerve-muscle contact was inadvertently disrupted during processing (Fig. $5 A-C$ ).

Labeling of cultured Xenopus neurons with anti-Na/Ca exchanger antibody was not continuous, but occurred as small $(<0.5 \mu \mathrm{m}$ diameter) patches (Figs. $3 A ; 5 A, D, E)$. This pattern did not appear to be a fixation artifact, as similar patches were observed in cultures fixed with formaldehyde (not shown), formaldehyde/amine (see Materials and Methods), or cold organic solvents (acetone, ethanol; not shown). Furthermore, these patches were observed whether the cultures were permeabilized with Brij 58 (see Materials and Methods) or saponin (not shown). A similar patchy distribution has been observed in cultured rat hippocampal neurons (R. K. Yip and M. P. Blaustein, unpublished observations). A much finer, punctate distribution of label was seen in cultured vascular smooth muscle cells (Blaustein et al., 1992). Similar punctate labeling was also observed on the Xenopus muscle cell surface (not shown). This labeling was much dimmer and more diffuse than that in the neurons, and was comparable in intensity to the low level of labeling observed in the extrajunctional sarcolemma of mammalian skeletal muscle (Fig. 2A,E). The cultures had to be permeabilized, however, for such labeling to be detected in both the neurons and myocytes, 
Figure 4. Three pseudocolor images from the data in Figure $3 A-C$, respectively, superimposed to show the distribution of the $\mathrm{Na} / \mathrm{Ca}$ exchanger. Fluorescent labeling for the $\mathrm{Na} / \mathrm{Ca}$ exchanger is shown in green, and for the postjunctional ACh receptors, in red; the nerve and muscle cells are shown in blue. For clarity, the green image was subtracted from the red and blue images to eliminate overlap of the colors.

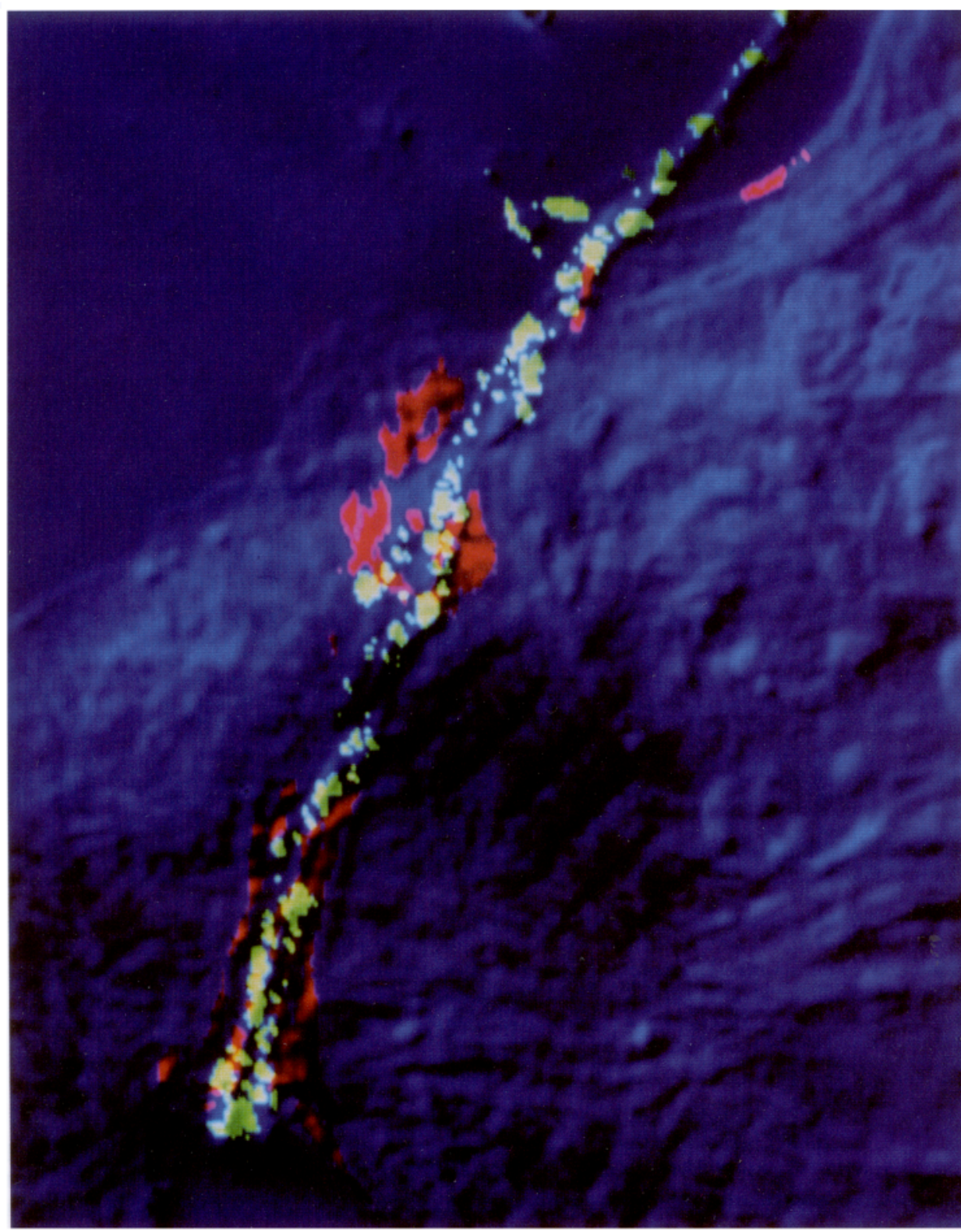

presumably because most of the epitopes recognized by the antiserum used for these experiments were located at the cytoplasmic face of the plasmalemma.

Punctate labeling of the $\mathrm{Na} / \mathrm{Ca}$ exchanger was not limited to NMJs in the cultured neurons, but extended along the entire length of the axon (Figs. $3 A, 5 A$ ). Labeling was also observed on growth cones (Fig. $5 D$ ) and in the soma, where it was apparent that the patches of exchanger were limited to the cell surface (Fig. 5E).

\section{Discussion}

The $\mathrm{Na} / \mathrm{Ca}$ exchanger is concentrated at nerve terminals and in other neuronal regions where there may be a large turnover of $\mathrm{Ca}^{2+}$

The data from cryosectioned rat diaphragm (Fig. 2) demonstrate that high densities of $\mathrm{Na} / \mathrm{Ca}$ exchanger molecules are specifically localized at NMJs. The results from the Xenopus coculture sys- tem (Figs. 3-5) establish that exchanger molecules are present in the neuron, where they are organized into microdomains. The immunoblot data (Fig. 1) indicate that the exchanger is present in much higher density in nervous tissues of adult rats that contain synapses (cerebral cortex and spinal cord) than in peripheral nerve. These findings all suggest a predominantly presynaptic location of the $\mathrm{Na} / \mathrm{Ca}$ exchanger. They are consistent with physiological studies on rat brain synaptosomes that indicate that the density of exchanger in nerve terminals is high enough to mediate a large $\mathrm{Ca}^{2+}$ flux (about 1.5-2 $\mathrm{nmol} \mathrm{Ca}{ }^{2+}$ $\mathrm{mg}$ protein/sec) (Blaustein et al., 1991; Fontana and Blaustein, 1991).

The immunofluorescence data demonstrate that the $\mathrm{Na} / \mathrm{Ca}$ exchanger in neurons is also concentrated in the plasmalemma of growth cones and developing axons, and is present at lower concentrations in the plasmalemma of cell bodies and mature axons. This distribution may reflect the relative rates of trans- 

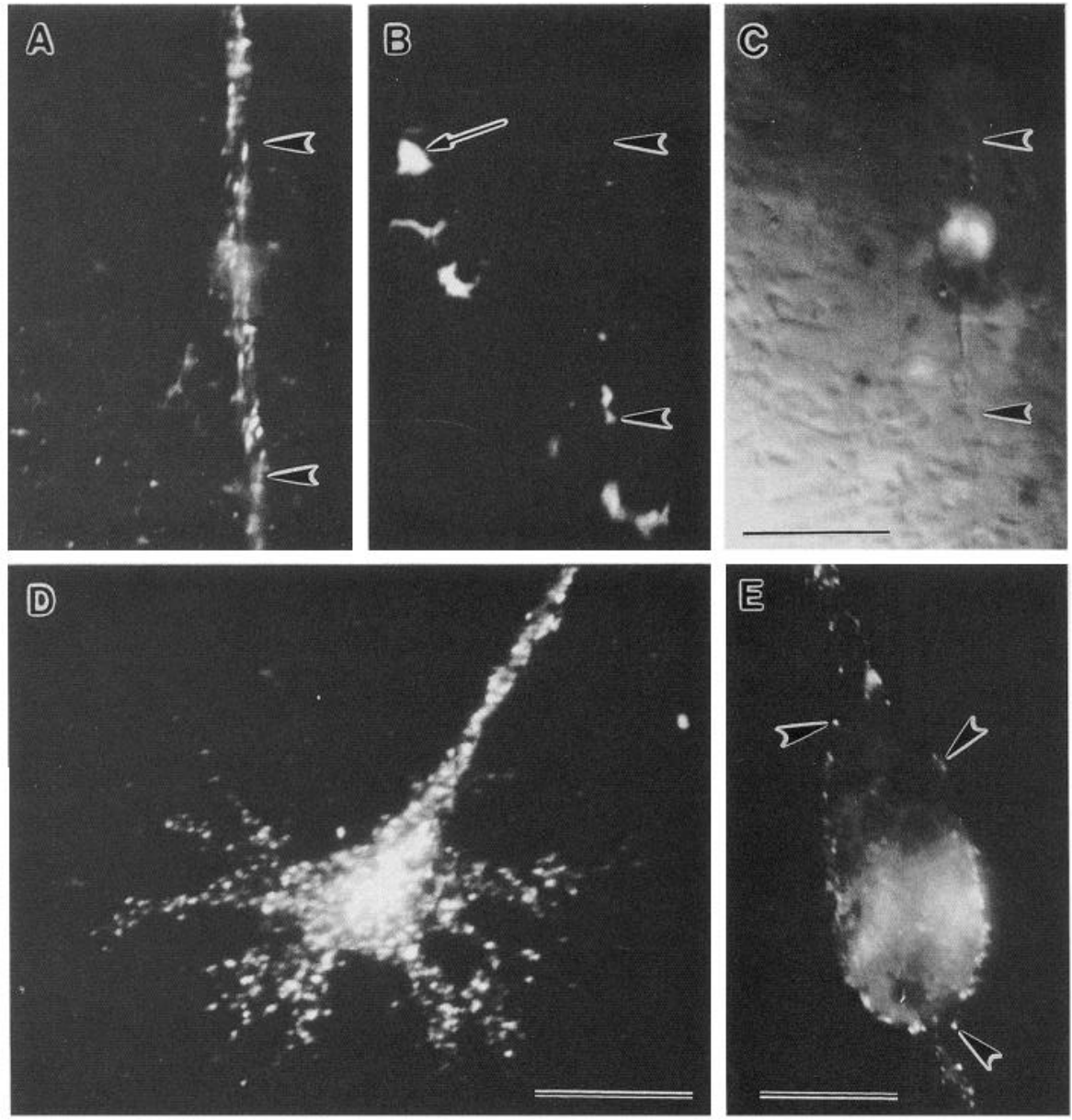

Figure 5. Immunofluorescent labeling of $\mathrm{Na} / \mathrm{Ca}$ exchanger in cultured Xenopus neurons. $A-C$, A neuron labeled with affinity-purified anti- $\mathrm{Na} / \mathrm{Ca}$ exchanger $(A)$ was displaced from the postjunctional region (arrow in $B$ ) during tissue processing. $C$, Differential interference contrast micrograph of the same cells. The position of the neuron is indicated by the arrowheads in $A-C$. $D$, Neuronal growth cone labeled with affinity-purified antibody. The label occurs in patches that extend into the filopodia. $E$, Similar, but sparser, patches labeled by the affinity-purified antibody are observed on the neuronal soma. The labeling appears confined to the cell surface (arrowheads); the large bright area near the nucleus is due to nonspecific labeling by the secondary antibody. Scale bars, $10 \mu \mathrm{m}(C$ for $A-C)$. membrane transport of $\mathrm{Ca}^{2+}$ in these regions. In developing neurons, $\mathrm{Ca}^{2+}$ (much of it derived from the extracellular fluid) plays critical roles in motility (Kater et al., 1988; Kater and Mills, 1991) and excitability (Baccaglini and Spitzer, 1977; Spitzer, 1979). In the axons and cell bodies of mature neurons, $\mathrm{Ca}^{2+}$ may simply serve a "background role," and may help to mobilize metabolic machinery (Hille, 1992). The limited traffic of $\mathrm{Ca}^{2+}$ across the plasma membrane at these sites may require only low levels of $\mathrm{Na} / \mathrm{Ca}$ exchanger to help maintain $\left[\mathrm{Ca}^{2+}\right]_{\text {cyt }}$.

The activity (turnover) of the $\mathrm{Na} / \mathrm{Ca}$ exchanger is low in most cells under resting conditions because both $\mathrm{Ca}^{2+}$ influx and efflux mediated by the exchanger are half-maximally activated by $\left[\mathrm{Ca}^{2+}\right]_{\mathrm{cyt}}$ of $\simeq 10^{-6} \mathrm{M}$ (Blaustein et al., 1991; Fontana and Blaustein, 1991). During nerve depolarization, $\mathrm{Ca}^{2+}$ entering through voltage-gated channels will raise $\left[\mathrm{Ca}^{2+}\right]_{\mathrm{cyt}}$ and saturate regulatory and transport sites on the exchanger, but the electrical driving force will oppose $\mathrm{Ca}^{2+}$ efflux via the voltage-sensitive $\mathrm{Na} / \mathrm{Ca}$ exchanger. Upon repolarization, however, with a high $\left[\mathrm{Ca}^{2+}\right]_{\text {cyy }}$, the electrical driving force will exceed the exchanger's reversal potential and will strongly favor $\mathrm{Ca}^{2+}$ extrusion via the exchanger (Blaustein, 1989). Thus, the exchanger may play a key role in the extrusion of $\mathrm{Ca}^{2+}$ during recovery following activation (Sanchez-Armass and Blaustein, 1987; Fontana and Blaustein, 1991). This could be especially important at nerve terminals and growth cones, and perhaps at dendritic spines (Westenbroek et al., 1990), where $\mathrm{Ca}^{2+}$ influx is large and the cell surface:volume ratio is high.

\section{Possible role(s) of the $\mathrm{Na} / \mathrm{Ca}$ exchanger in the regulation of neurotransmitter release}

Neurotransmitter release is triggered by depolarization-activated $\mathrm{Ca}^{2+}$ entry at nerve terminals, and is rapidly reduced by repolarization (half-time $=1-2 \mathrm{msec}$; Katz, 1969). Parnas and colleagues (Dudel et al., 1983; Parnas and Parnas, 1988) have suggested that the release process per se is voltage sensitive, although membrane depolarization is not essential for release (Zucker and Landò, 1986; Mulkey and Zucker, 1991). Recently, Arechiga and colleagues concluded that the $\mathrm{Na} / \mathrm{Ca}$ exchanger did not participate in this voltage-sensitive process because a reduction of the extracellular $\mathrm{Na}^{+}$concentration from 220 to $110 \mathrm{~mm}$ did not affect the rapid inhibition of facilitation that was promoted by sudden hyperpolarization at the crayfish NMJ (Arechiga et al., 1990). However, $110 \mathrm{~mm} \mathrm{Na}^{+}$is sufficient to saturate the external $\mathrm{Na}^{+}$sites on the $\mathrm{Na} / \mathrm{Ca}$ exchanger (Sanchez-Armass and Blaustein, 1987), so this is not a critical test of the role of the exchanger in terminating transmitter release. The high density of the exchanger at nerve terminals (present results), the large flux of $\mathrm{Ca}^{2+}$ mediated by the voltage-sensitive $\mathrm{Na} / \mathrm{Ca}$ exchanger at nerve terminals (Blaustein et al., 1991; Fontana and Blaustein, 1991), and the apparent voltage sensitivity of transmitter release (Katz, 1969; Dudel et al., 1983; Parnas and Parnas, 1988) all are consistent with the hypothesis that repolarization-activated extrusion of $\mathrm{Ca}^{2+}$ via $\mathrm{Na} / \mathrm{Ca}$ exchange may be important for the rapid removal of $\mathrm{Ca}^{2+}$ from 
release sites and for the termination of transmitter release. During activation, the greatest rise in $\left[\mathrm{Ca}^{2+}\right]_{\text {eyt }}$ occurs in close proximity to the active zones, where it may transiently reach levels of $\geq 0.1 \mathrm{~mm}$ (Smith and Augustine, 1988). Subcellular localization experiments are now needed to determine whether exchanger molecules at the terminals are situated close to active zones, where they could participate directly in the termination of transmitter release, or only at more distant sites, where they would be involved in the slightly delayed net extrusion of $\mathrm{Ca}^{2+}$ (Blaustein, 1988a,b).

\section{References}

Ambesi A, Bagwell EE, Lindenmayer GE (1991) Purification and identification of the cardiac sarcolemmal $\mathrm{Na} / \mathrm{Ca}$ exchanger. Biophys J 59: $138 \mathrm{a}$.

Anderson MJ, Cohen MW, Zorychta E (1977) Effects of innervation on the distribution of acetylcholine receptors on cultured amphibian muscle cells. J Physiol (Lond) 268:731-756.

Arechiga H, Cannone A, Parnas H, Parnas I (1990) Blockage of synaptic release by brief hyperpolarizing pulses in the neuromuscular junction of the crayfish. J Physiol (Lond) 430:119-133.

Atwood HL, Charlton MP, Thompson CS (1983) Neuromuscular transmission in crustaceans is enhanced by a sodium ionophore, monensin, and by prolonged stimulation. J Physiol (Lond) 335:179-195.

Baccaglini PI, Spitzer NC (1977) Developmental changes in the inward current of the action potential of Rohon-Beard neurones. J Physiol (Lond) 271:93-117.

Blaustcin MP (1988a) Calcium and synaptic function. Handb Exp Pharmacol 83:275-304.

Blaustein MP (1988b) Calcium transport and buffering in neurons. Trends Neurosci 11:438-443.

Blaustein MP (1989) Sodium/calcium exchange in cardiac, smooth and skeletal muscles: key to the control of contractility. Curr Top Membr Transp 34:289-330.

Blaustein MP, Goldman WF, Fontana G, Krueger BK, Santiago EM, Steele TD, Weiss DN, Yarowsky PJ (1991) Physiological roles of the sodium-calcium exchanger in nerve and muscle. Ann NY Acad Sci 639:254-274.

Blaustein MP, Ambesi A, Bloch RJ, Goldman WF, Juhaszova M, Lindenmayer GE, Weiss DN (1992) Regulation of vascular smooth muscle contractility: roles of the sarcoplasmic reticulum (SR) and the sodium/calcium exchanger. Jpn J Pharmacol 58(suppl II):107P-1 14P.

DiPolo R, Beaugé L (1990) Calcium transport in excitable cells. In: Intracellular calcium regulation (Bronner F, ed), pp 305-347. New York: Liss.

Dudel J, Parnas I, Parnas H (1983) Neurotransmitter release and its facilitation in crayfish muscle. VI. Release determined by both intracellular calcium concentration and depolarization of the nerve terminal. Pfluegers Arch 399:1-10.

Durkin JT, Ahrens DC, Aceto JF, Condrescu M, Reeves JP (1991a) Molecular and functional studies of the cardiac sodium-calcium exchanger. Ann NY Acad Sci 639:189-201.
Durkin JT, Ahrens DC, Pan Y-CE, Reeves JP (1991b) Purification and amino-terminal sequence of the bovine cardiac sodium-calcium exchanger: evidence for the presence of a signal sequence. Arch Biochem Biophys 290:369-375.

Fontana G, Blaustein MP (1991) Kinetics of $\mathrm{Na} / \mathrm{Ca}$ exchange in rat brain presynaptic terminals. Soc Neurosci Abstr 17:1326.

Hille B (1992) Ionic channels of excitable membranes, 2d ed, p 114. Sunderland, MA: Sinauer.

Kater SB, Mills LR (1991) Regulation of growth cone behavior by calcium. J Neurosci 11:891-899.

Kater SB, Mattson MP, Cohan C, Connor J (1988) Calcium regulation of the neuronal growth cone. Trends Neurosci 11:315-321.

Katz B (1969) The release of neural transmitter substances. Springfield, IL: Thomas.

Luther PW, Bloch RJ (1989) Formaldehyde-amine fixatives for immunocytochemistry of cultured Xenopus myocytes. J Histochem Cytochem 37:75-82.

Meiri H, Erulkar SD, Lerman T, Rahamimoff R (1981) The action of the sodium ionophore, monensin, on transmitter release at the frog neuromuscular junction. Brain Res 204:204-208.

Misler S, Hurlbut WP (1983) Post-tetanic potentiation of acetylcholine release at the frog neuromuscular junction develops after stimulation in $\mathrm{Ca}^{2+}$-free solutions. Proc Natl Acad Sci USA 80:315-319.

Mulkey RM, Zucker RS (1991) Action potentials must admit calcium to evoke transmitter release. Nature 350:153-155.

Nicoll DA, Longoni S, Philipson KD (1990) Molecular cloning and functional expression of the cardiac sarcolemmal $\mathrm{Na}^{+}-\mathrm{Ca}^{2+}$ exchanger. Science 250:562-565.

Parnas I, Parnas H (1988) The 'Ca-voltage' hypothesis for neurotransmitter release. Biophys Chem 29:85-93.

Philipson KD, Longoni S, Ward R (1988) Purification of the cardiac $\mathrm{Na}^{+}-\mathrm{Ca}^{2+}$ exchange protein. Biochim Biophys Acta 945:298-306.

Sanchez-Armass S, Blaustein MP (1987) Role of $\mathrm{Na} / \mathrm{Ca}$ exchange in the regulation of intracellular $\mathrm{Ca}^{2+}$ in nerve terminals. Am J Physiol 252:C595-C603.

Smith SJ, Augustine GJ (1988) Calcium ions, active zones and synaptic transmitter release. Trends Neurosci 11:458-464.

Spitzer NC (1979) Ion channels in development. Annu Rev Neurosci 2:363-397.

Weldon PR, Cohen MW (1979) Development of synaptic ultrastructure at neuromuscular contacts in an amphibian cell culture system. J Neurocytol 8:239-259.

Westenbroek RE, Ahlijanian MK, Catterall WA (1990) Clustering of L-type $\mathrm{Ca}^{2+}$ channels at the base of major dendrites in hippocampal pyramidal neurons. Nature 347:281-284.

Yip RK, Blaustein MP, Philipson KD (1992) Immunologic identification of $\mathrm{Na} / \mathrm{Ca}$ exchange protein in rat brain synaptic plasma membrane. Neurosci Lett 136:123-126.

Zucker RS, Landò L (1986) Mechanisms of transmitter release: voltage hypothesis and calcium hypothesis. Science 231:574-579.

Zucker RS, Delaney KR, Mulkey R, Tank DW (1991) Presynaptic calcium in transmitter release and post-tetanic potentiation. Ann NY Acad Sci 639:191-207. 